\title{
Erratum to comparative study of one-stage and the novel two-stage urethroplasty using the transected urethral plate and transverse preputial island flap (TPIF) for severe hypospadias: a single-center experience
}

\author{
Editorial Office \\ Translational Pediatrics \\ Correspondence to: Editorial Office. Translational Pediatrics. Email: editor@thetp.org. \\ Submitted Sep 30, 2021. Accepted for publication Oct 01, 2021. \\ doi: $10.21037 / \mathrm{tp}-21-475$ \\ View this article at: https://dx.doi.org/10.21037/tp-21-475
}

Erratum to: Transl Pediatr 2021;10:843-50

The article entitled "Comparative study of one-stage and the novel two-stage urethroplasty using the transected urethral plate and transverse preputial island flap (TPIF) for severe hypospadias: a single-center experience” (1) that appeared on Page: 843-850, Vol 10, No. 4 (April 2021) unfortunately contained a mistake in the section of title page. The corrected information is presented as below.

The affiliation of the corresponding authors of Dr. Zheng Ge and Dr. Yunfei Guo should be "Department of Urology, Children's Hospital of Nanjing Medical University, Nanjing, China" rather than "Department of Urology, The Affiliated Children's Hospital of Nanjing Medical University, Nanjing, China”.

Click here to view the updated version of the article.

Open Access Statement: This is an Open Access article distributed in accordance with the Creative Commons AttributionNonCommercial-NoDerivs 4.0 International License (CC BY-NC-ND 4.0), which permits the non-commercial replication and distribution of the article with the strict proviso that no changes or edits are made and the original work is properly cited (including links to both the formal publication through the relevant DOI and the license). See: https:// creativecommons.org/licenses/by-nc-nd/4.0/.

\section{References}

1. Zhu X, Huang L, Wang J, et al. Comparative study of one-stage and the novel two-stage urethroplasty using the transected urethral plate and transverse preputial island flap (TPIF) for severe hypospadias: a single-center experience. Transl Pediatr 2021;10:843-50.

Cite this article as: Editorial Office. Erratum to comparative study of one-stage and the novel two-stage urethroplasty using the transected urethral plate and transverse preputial island flap (TPIF) for severe hypospadias: a single-center experience. Transl Pediatr 2021;10(10):2882. doi: 10.21037/tp-21-475 